\title{
Kollegiala samtal som kontext för utveckling av lärares literacyförståelse
}

\author{
Ann-Christin Randahl och Pernilla Andersson Varga \\ Göteborgs universitet
}

\section{Sammanfattning}

I denna artikel undersöks kollegiala samtals potential att utveckla lärares literacyförståelse. Två samtal i den statliga fortbildningssatsningen Läslyftet analyseras. Inför samtalen har deltagarna läst artiklar om literacy, som ska diskuteras. I det första samtalet deltar en ämnesmässigt heterogen grupp gymnasielärare på ett yrkesprogram, medan en ämnesmässigt homogen grupp svensklärare från grundskolans senare år deltar i det andra samtalet. Båda samtalen leds av en handledare.

Även om samtalen på en övergripande nivå kretsar kring fortbildningens innehåll saknas tecken på ny eller fördjupad literacyförståelse. Orsakerna kan vara flera. I det första samtalet saknas en delad bild av undervisningspraktiken. Istället framträder en tydlig skillnad mellan yrkesämnets muntliga kultur och övriga skolämnens skriftburna kultur, som tycks försvåra möjligheterna att göra literacy till ett gemensamt lärandeobjekt. Det finns också tecken på att artikeln som diskuteras är svårtillgänglig för vissa deltagare. I det andra samtalet har lärarna en delad bild av undervisningspraktiken och en gemensam syn på literacy. Artikelinnehållet görs till utgångspunkt för långa berättelserundor och erfarenhetsutbyte, men erbjuder varken ny kunskap eller nya perspektiv som kan utmana lärarnas förförståelse.

Även handledarens roll antas ha betydelse för kunskapsbygget. Trots handledarnas förmodat epistemiska tillgång, förväntas de endast i liten utsträckning ta epistemiskt ansvar för fortbildningssatsningens literacyinnehåll.

\section{Nyckelord: Literacy; kollegialt lärande; handledare; Läslyftet; intersubjektivitet}

\begin{abstract}
Peer discussions as an arena for mutual knowledge building about literacy

In this article two peer discussions on literacy issues within the professional development programme Boost for reading are analyzed. The groups of teachers taking part in the discussions differ - one is a heterogeneous group of upper secondary teachers, whereas the other is a more homogenous group of late primary and secondary teachers. From a professional learning perspective (Stoll et al., 2006; Talbert, 2010), we examine the mutual knowledge building processes taking place and what impact the teachers' previous notions on literacy have. The peer discussions are led by a facilitator. Questions concerning the role of the facilitator are also raised.
\end{abstract}

\footnotetext{
^Korrespondanse: Ann-Christin Randahl, e-post: ann-christin.randahl@svenska.gu.se
} 
The role of the facilitator is complex and the two contexts require high and different demands on the facilitator handling the discussion. To facilitate knowledge building, taking the role as a moderator seems to be insufficient. Instead, the teachers are dependent upon the facilitator meditating the literacy issues as well as challenging prior knowledge.

Keywords: Literacy; facilitator; peer discussion; intersubjectivity; professional development programme

Responsible editor: Per Henning Uppstad

Received: December, 2019; Accepted: June, 2020; Published: December, 2020

\section{Inledning}

I svensk skola finns idag en växande medvetenhet om att alla lärare, oavsett skolform och skolämne, behöver ha en förståelse för språkets betydelse för kunskapsutvecklingen - det vill säga en förståelse av literacy (Skolverket, 2012, 2019; SOU 2018: 17, s. 564 ff.). Denna syn på literacy har också satt fokus på ämnesspecifikt språk och varje lärares ansvar för elevers språk- och kunskapsutveckling (Shanahan \& Shanahan, 2012). Vidare har andraspråksforskningen synliggjort utmaningar i skolspråket för de elever som läser, skriver och lär på sitt andraspråk (Cummins, 2017; Lahdenperä \& Sundgren, 2017). För att möta denna förändrade syn på literacy genomförs olika slags fortbildningssatsningar med syfte att stärka lärares kompetens att arbeta språk- och kunskapsutvecklande.

Läsåret 19/20 avslutas i Sverige en femårig statlig fortbildningssatsning om literacy, kallad Läslyftet. Läslyftet har två syften - dels att öka elevers måluppfyllelse, vilket antas bli följden av en språkmedveten undervisning, dels att införa en skolutvecklingsmodell som bygger på kollegialt lärande (Skolverket, 2018; Utbildningsdepartementet, 2013). Satsningen vänder sig därför till lärare i skolans alla undervisningsformer och ämnen. Fortbildningsmodellen innebär att lärare diskuterar forskningsbaserade artiklar (och filmer), planerar gemensamma undervisningsmoment, genomför och följer upp dessa. I satsningen har cirka 3500 skolor medverkat och över 40000 lärare deltagit. Dessutom har drygt 3600 handledare utbildats för att kunna leda de kollegiala samtal som ses som centrala i Läslyftet (Skolverket, personlig kommunikation, 4 april 2019).

Denna studie syftar till att undersöka vilken potential kollegiala samtal har för att utveckla och stärka lärares literacyförståelse. Tre frågor ställs:

- Vilket kunskapsbygge om literacy sker i de kollegiala samtalen?

- Vilka föreställningar om literacy kommer till uttryck i samtalen?

- Vilken roll spelar handledaren?

\section{Bakgrund}

I följande avsnitt presenteras inledningsvis tidigare forskning om fortbildning och skolutveckling genom kollegialt lärande. Därefter följer en beskrivning av Läslyftets 
upplägg och det kollegiala lärandets roll i satsningen. Avsnittet avslutas med en redogörelse för befintlig forskning om Läslyftet och utvärderingar som genomförts av satsningen.

\section{Fortbildning och skolutveckling genom kollegialt lärande}

På en policynivå framhålls kollegialt lärande som en viktig väg till skolutveckling (OECD, 2015; se även Jarl et al., 2017). Det finns också ett starkt vetenskapligt stöd att initiera och stödja kollegiala processer som leder till hållbara lärandegemenskaper, med syfte att öka undervisningens kvalitet. Tidigare studier har till exempel visat att skolor där lärare samarbetar är mer framgångsrika än skolor där lärarsamverkan saknas (Bolam et al., 2005; Hargreaves \& Fullan, 2013; Timperley, 2011). Hur detta samarbete organiseras och vilka föreställningar satsningar på kollegialt lärande bygger på har dock betydelse för i vilken utsträckning sådana initiativ lyckas. Talbert (2010) skiljer mellan byråkratiskt och professionellt inriktade satsningar. Kännetecknade för en mer byråkratiskt inriktad satsning är att det kollegiala lärandet implementeras uppifrån och att fokus ofta ligger på kontroll och benchmarking. Risken finns att undervisning med lätt mätbara resultat kommer i förgrunden, snarare än undervisning som fokuserar på att verkligen utveckla elevers kunskaper, menar Talbert. Byråkratiskt inriktade satsningar kan även skapa oro, motstånd eller opportunism bland lärare, vilket försvårar utvecklingen av mer hållbara professionella lärandegemenskaper. För att gynna utvecklingen av professionella lärandegemenskaper är det viktigt att lärare ges tillräckligt med tid för samtal och samverkan. Samtidigt leder tid inte per automatik till skolutveckling. Istället krävs, enligt Talbert, att lärarna är överens om vissa normer, främst att samarbete utvecklar undervisning och att undervisning påverkar elevernas lärande. Dessa normer utmärker vad Talbert betecknar en professionell föreställning om kollegialt lärande.

Liknande slutsatser formuleras i en känd metastudie (Stoll et al., 2006) om karakteristika för välfungerande professionella lärandegemenskaper (professional learning communities, PLC). I studien identifieras fem faktorer: gemensamma värderingar och visioner, delat ansvar för elevers lärande, reflekterande förhållningssätt, samarbete och gemensamt kunskapsbygge. Förutom dessa fem faktorer har Stoll et al. i egen forskning identifierat ytterligare tre: ömsesidig respekt och tillit, inkludering av all personal samt öppenhet och nätverksbygge.

För att utreda i vilken utsträckning kollegiala samtal fungerar som en resurs för kunskapsbygge med målet att utveckla den egna undervisningen har Little (2002) undersökt kollegiala samtal ur tre perspektiv: vilken bild av undervisningspraktiken som framträder (representation of practice), vad lärarna beskriver som möjligt att förändra (orientation toward practice) och hur samtalet är strukturerat (norms of interaction). I samtalen identifierar Little spänningar mellan kollektiva åtaganden och den enskilde lärarens autonomi. Hon konstaterar också att det finns skillnader mellan hur lärare föreställer sig syftet med kollegial samverkan. Vissa anser att samverkan bör 
syfta till att kritiskt och strukturerat utforska undervisningens praktik, medan andra anser att samverkan bör syfta till att lösa morgondagens lektioner.

\section{Läslyftets upplägg}

Läslyftets modell för kollegialt lärande består av fyra olika moment: A, B, C och D (se Figur 1).

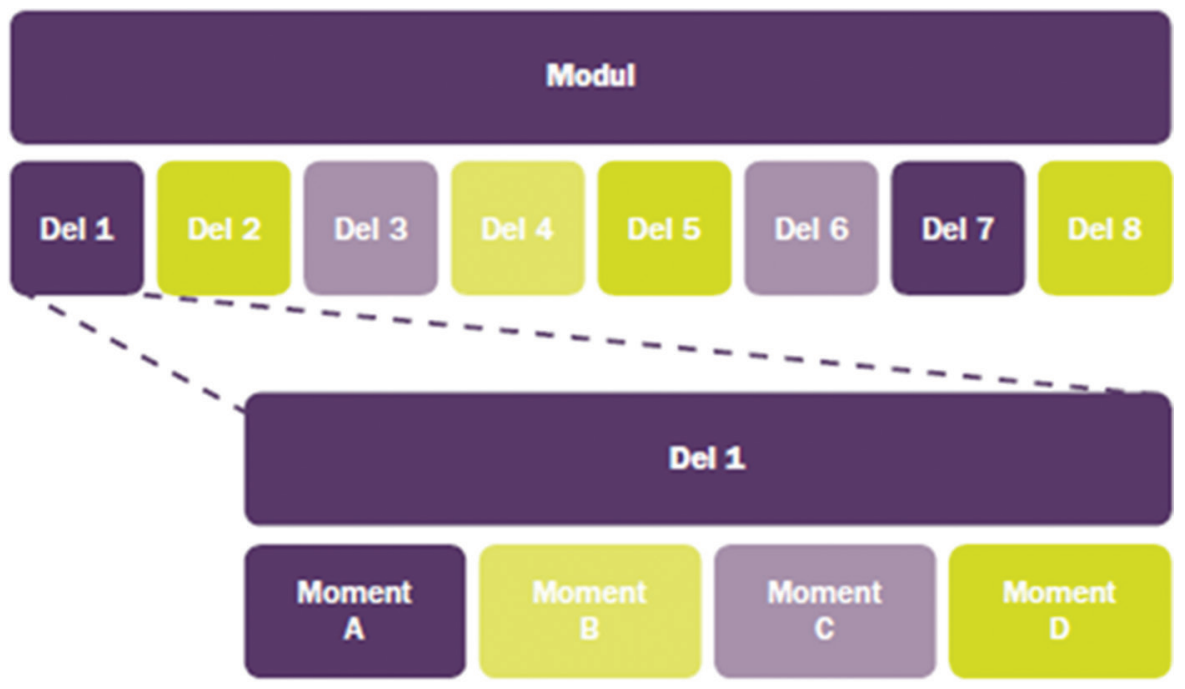

\section{De fyra momenten:}

\section{A Individuell förberedelse}

B Kollegialt arbete

C Undervisningsaktivitet

D Gemensam uppföljning
45-60 minuter

90-120 minuter

lektionstid

45-60 min

Figur 1. Läslyftets fortbildningsmodell (Skolverket, 2018, s. 6)

I moment A förbereder sig lärarna individuellt genom att ta del av en artikel och eventuella filmer. Artiklarna är uppbyggda runt teman i så kallade moduler, som är framtagna av olika svenska lärosäten i samverkan med Skolverket. En del av modulerna riktar sig till specifika skolformer eller ämnesområden men det finns också mer generella moduler som riktar sig till lärare i flera ämnen och/eller skolformer. Denna studie bygger på kollegiala samtal om artiklar i två sådana generella moduler.

I moment B träffas lärarna och handledaren för att diskutera innehållet i artiklar och eventuella filmer. Dessutom ska en undervisningsaktivitet, moment C, planeras. 


\section{A.-C. Randahl och P. A. Varga}

Denna aktivitet förväntas lärarna genomföra i sina respektive klasser. Därefter träffas lärarna och handledaren åter för ett kollegialt samtal, i moment $\mathrm{D}$, där man diskuterar och reflekterar över sina erfarenheter av den genomförda undervisningsaktiviteten. Varannan vecka genomförs ett B-samtal och varannan vecka ett D-samtal. I denna studie undersöks två B-samtal.

Läslyftets fortbildningsmodell bygger på en tidigare genomförd satsning på matematikämnet, det så kallade Matematiklyftet. Båda fortbildningssatsningarna har stora likheter med Timperleys (2008) cykliska process för professionellt lärande (se Figur 2). En viktig skillnad är dock att svaret på vilken kunskap elever och lärare behöver utveckla (del 1 och 2 i modellen) är formulerade på förhand i de moduler som erbjuds i satsningarna. I Timperleys modell har lärarna en större agens i dessa delar.

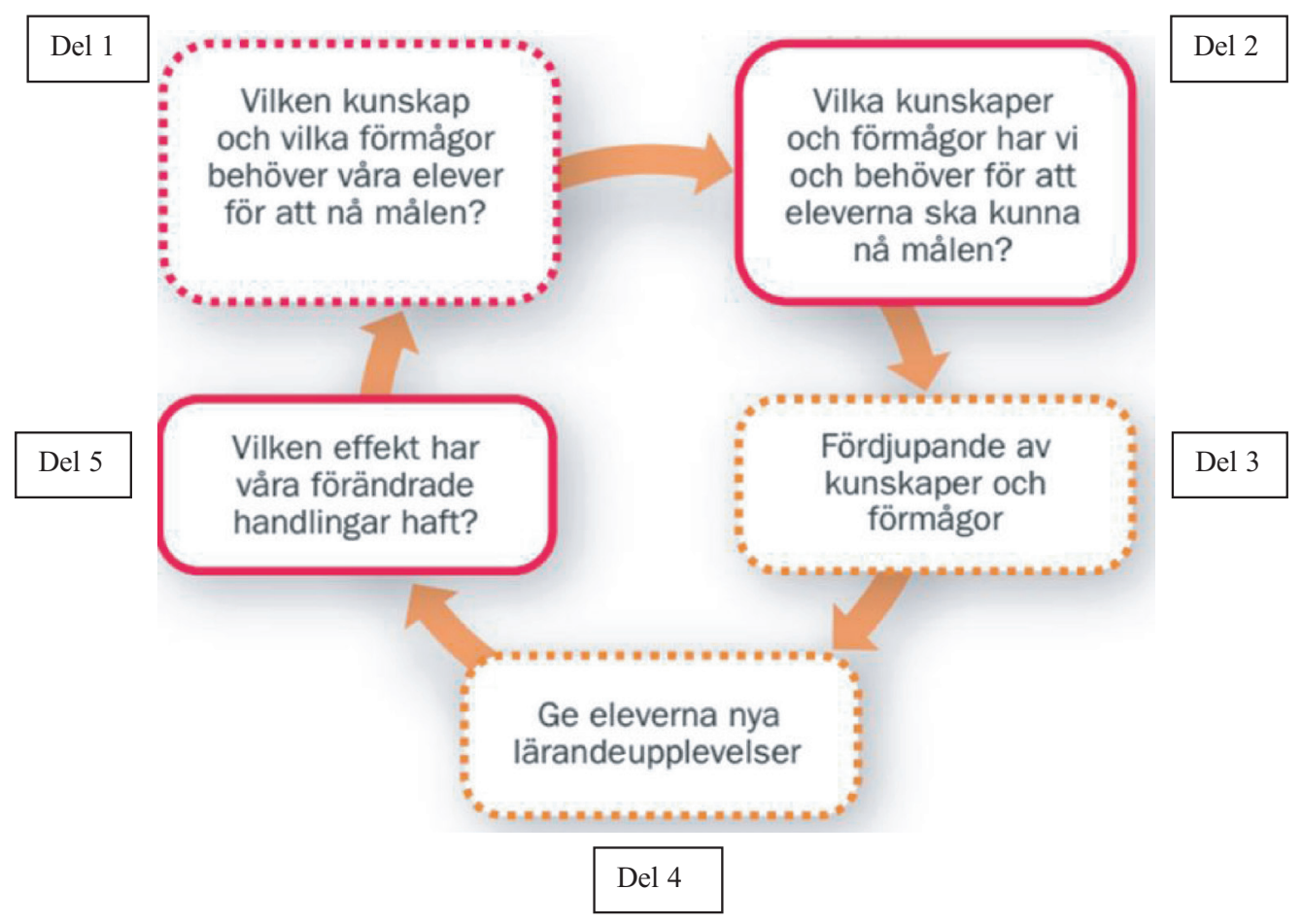

Figur 2. Timperleys modell för professionellt lärande (i svensk bearbetning av Minten, 2013, s. 28)

B-samtalen fokuserar på del 2 och framförallt på del 3, "Fördjupande av kunskaper och förmågor", i processen. Det är i denna fas som lärarna gemensamt förväntas bygga kunskap kring det innehåll som artiklar och filmer förmedlar. Samtliga moduler adresserar på olika sätt frågor om literacy. Eftersom Läslyftet vänder sig till lärare i alla ämnen är det rimligt att anta att delar av artikelinnehållet är mer lättillgängligt eller bekant för lärare i något av svenskämnena än för lärare i andra ämnen. 
En bärande tanke i Läslyftet är alltså att det kollegiala lärandet förstärks genom kollegiala samtal (jfr Larsson, 2018). För att leda sådana samtal utbildas lärare i något av svenskämnena till handledare. I utbildningen presenteras olika modeller för strukturerade samtal. Två vanligt förekommande modeller är lärande samtal och kollegahandledning, som båda bygger på en struktur där alla lärare får komma till tals. Det övergripande syftet med lärande samtal är att skapa mening och förståelse samt förutsättningar för att upptäcka andra(s) perspektiv. Detta antas ske då deltagare reflekterar tillsammans (Scherp, 2003). Fokus ligger på lärares lärande snarare än görande i klassrummet. Kollegahandledning som samtalsmodell (Lauvås et al., 1997) karakteriseras av en fastare samtalsstruktur och ett tydligare lösningsfokus jämfört med det lärande samtalet. I en inledande samtalsrunda presenterar deltagarna i tur och ordning varsitt upplevt dilemma. Därefter väljs ett av dessa dilemman ut. I nästa steg ställer övriga deltagare öppna frågor, som dilemmaägaren själv ska försöka finna svar på. Tanken är att det kollegiala lärandet främjas av att fler lärare känner igen sig i dilemmat och därmed får handlingsberedskap för en motsvarande situation.

I Läslyftet ges handledaren framförallt rollen som samtalsledare eller moderator för de kollegiala samtalen. Denna roll lyfts fram i Skolverkets presentation av fortbildningssatsningen: "Handledaren är framförallt en samtalsledare i det kollegiala arbetet" (Skolverket, 2018, s. 13). En tidigare publicerad enkätstudie (Varga \& Randahl, 2017) har visat att handledarna själva också identifierar sig med denna roll. Rollen som samtalsledare är därmed både förväntad och upplevd (Thornberg, 2013).

Det finns också en förväntan om att handledaren ska kunna ta rollen som en slags literacyexpert och mediera innehållet i modulerna. Denna roll är mer implicit framskriven i Läslyftet och beskrivs som att handledaren ska kunna "vägleda deltagarna på Lärportalen" (Skolverket, 2018, s. 13). Vikten av att lärare som utses att leda kollegialt lärande har en gedigen kunskapsbas framhålls i tidigare forskning (se t.ex. Fjørtoft, 2016; Muijs \& Harris, 2003; Talbert, 2010): "accomplished and well-networked teachers are pivotalt to a PLC's learning" (Talbert, 2010, s. 559). I ovan nämnda enkätstudie om handledarna i Läslyftet (Varga \& Randahl, 2017) framgår att en majoritet av 61 tillfrågade handledare är välmeriterade och har lång undervisningserfarenhet. Två tredjedelar av dem (38 st.) uppger att de har tidigare handledarerfarenhet. En lika stor andel (39 st.) har en tjänst som läs- och skrivutvecklare eller förstelärare. Endast fyra handledare uppger "enbart" lärarutbildning i något av svenskämnena, vilken utgör det formella kravet för handledaruppdraget. Trots handledarnas förhållandevis gedigna bakgrund avvisas expertrollen: "För gruppens utveckling är det inte viktigt att jag vet mer än dom andra, snarare tvärtom, då gruppens samsyn och gruppens balans kan rubbas om det framstår som provocerande eller om jag som ledare är en expert” (Varga \& Randahl, 2017, s. 314). För handledarna förefaller de båda rollerna som moderator och en slags expert på literacy motsatta och oförenliga, snarare än komplementära och önskvärda. 


\section{A.-C. Randahl och P. A. Varga}

\section{Forskning om och utvärderingar av Läslyftet}

Antalet publicerade forskningsstudier om Läslyftet är ännu anmärkningsvärt få med tanke på satsningens omfattning. I en textanalytisk studie av Erixon och Löfgren (2018) undersöks kopplingen mellan läsning av skönlitteratur och skolans demokratiska uppdrag och i vilken utsträckning Läslyftet bidrar till att implementera en sådan undervisning. De konstaterar att skönlitteraturens roll är nedtonad och menar att ett färdighetsperspektiv dominerar satsningen. Johansson och Magnusson (2019) har med textanalytiska redskap undersökt innehållet i en Läslyftsartikel och hur detta innehåll tas emot av lärarna. I resultaten beskrivs en bristande matchning mellan innehållet som erbjuds och lärarnas förförståelse och behov, vilket i sin tur skapar ett motstånd hos deltagande lärare. Artikelförfattarna tolkar detta motstånd som ett uttryck för att satsningen ifrågasätter deltagarnas läraridentitet. I en observationsstudie av 20 kollegiala samtal med en grupp svensklärare undersöktes vilka lärandeobjekt som deltagarna orienterade sig mot i samtalen (Randahl, 2017). Fyra olika lärandeobjekt identifierades: begrepp, metoder och modeller för undervisning, gemensamma normer och värderingar samt en modell för utvecklingsarbete.

Läslyftet har utvärderats av Umeå universitet i tretton delrapporter, där delrapporterna 2 och 4 är av särskilt intresse för denna studie. I delrapport 2 (Carlbaum et al., 2016) undersöktes grundskolors erfarenheter och bedömningar av Läslyftets effekter. I rapporten konstateras att majoriteten av huvudmän, rektorer och handledare, samt fyra av tio lärare, anser satsningen vara "mycket bra". Av de undersökta målgrupperna är handledarna den mest positiva. En av tre handledare skattar kvaliteten på handledarutbildningen som "mycket hög" och fyra av tio att den har varit "ganska hög". Handledaruppdraget anses i stor utsträckning ha bidragit till att öka deras insikter i och engagemang för språk-, läs- och skrivutveckling, samt till att stärka deras allmänna didaktiska tänkande. Dessutom anser handledarna att Läslyftet har ökat deras intresse för kollegial samverkan och deras förmåga att handleda kollegor.

Även tillfrågade lärare menar att Läslyftet har haft stor effekt på deras insikter om språk-, läs- och skrivutvecklingsfrågor och om det kollegiala lärandet. Hälften av lärarna anser att fortbildningsmaterialet i hög utsträckning bidragit till ökad kunskap och kompetens i dessa frågor och de rapporterar att de använder sina nya insikter $\mathrm{i}$ sin undervisning. När det gäller Läslyftets effekter på elevers läs- och skrivkompetens uppfattar rektorer och lärare dem hittills vara begränsade och osäkra. Däremot anser man att Skolverket med denna fortbildningssatsning har bidragit till att etablera och stärka en skolutvecklingsmodell för kollegialt lärande.

I Delrapport 4 (Carlbaum et al., 2017) redogör gymnasieskolans aktörer för sina erfarenheter och bedömningar av Läslyftet. Resultaten liknar i hög utsträckning dem från grundskolan. Den skillnad som rapportförfattarna lyfter fram är att gymnasieskolans huvudmän, rektorer, handledare och framförallt lärare bedömer satsningens effekter som lägre än grundskolans målgrupper. 


\section{Material och metod}

I denna studie undersöks kollegiala samtal som kontext för utveckling av lärares literacyförståelse. Materialet består av två ljudinspelade och transkriberade B-samtal, samtal 1 och samtal 2, ledda av två olika handledare. I B-samtalen förväntas lärarna gemensamt bygga kunskap genom att diskutera det literacyinnehåll som den aktuella artikeln vill förmedla (moment A). Därför valdes B-samtal ut. Visserligen kan även D-samtal antas beröra artikelinnehållet, men i dessa samtal står uppföljningen av den genomförda undervisningsaktiviteten (moment $\mathrm{C}$ ) i förgrunden. Därför valdes D-samtal bort. Under båda samtalen diskuteras artiklar hämtade från moduler som riktar sig till lärare i alla ämnen. Valet av generella moduler, som riktar sig till lärare i alla ämnen, grundar sig i Läslyftets målsättning att göra alla lärare kompetenta att arbeta språk- och kunskapsutvecklande. Det första samtalet sker i en ämnesmässigt heterogen grupp och det andra i en ämnesmässigt homogen grupp svensklärare. Genom att variera kontexten för samtalen ville vi undersöka vilken roll deltagarnas förförståelse och föreställningar om literacy kan spela för att tillgodogöra sig fortbildningsmaterialet. I den ämnesmässigt heterogena lärargruppen, som till stor del består av yrkeslärare vars lärarexamen inte inbegriper studier om literacy (SFS 2013:1118), kan man anta att förförståelsen för satsningens literacyinnehåll är mer begränsad. Det motsatta gäller för den ämnesmässigt homogena lärargruppen där samtliga deltagare, genom sin grundutbildning, kan antas ha en större förförståelse för satsningens literacyinnehåll.

I samtal 1 diskuteras artikeln "Att bearbeta text - före läsandet" (Hallesson \& Visén, 2016), som ingår i modulen "Språk- och kunskapsutvecklande arbete". I förberedelsematerialet ingår även en film. Samtalet är 82 minuter långt och består av 408 turer. I samtalet deltar nio personer: handledaren (HL), fem lärare i yrkesämnen på gymnasiets fordonsprogram (Lärare A-E), en lärare i svenska (Lärare F), en bibliotekarie (B) och en rektor (R).

I samtal 2 diskuteras artikeln "Elever skriver" (Randahl \& Wengelin, 2015) som fanns i modulen "Att tolka och skriva text i skolans alla ämnen". ${ }^{1}$

Samtalet är 55 minuter långt och består av 239 turer. I samtalet deltar fem personer: handledaren (HL), två svensklärare på två olika högstadieskolor (Lärare 1 och 2) och två klasslärare på en mellanstadieskola (Lärare 3 och 4) (se Tabell 1).

Samtalen har transkriberats i sin helhet i en form där uttal anpassats efter rådande stavningsnorm. Vissa talspråkliga uttryck har dock behållits (se Kvale \& Brinkman, 2014). Utelämnad text i citat markeras med klammer och tre punkter [...]. Pauser markeras med parentes och tre punkter (...). Överlappande tal eller prosodi markeras inte. Vi har bedömt att en sådan noggrannhet $i$ transkriptionen inte är nödvändig $i$ relation till studiens syfte. Kursiveringar i fetstil i vissa citat markerar språkliga val som vi vill uppmärksamma. För att skydda deltagarnas identitet har vi avstått från

\footnotetext{
${ }^{1}$ Modulen har reviderats och heter nu "Att tolka och skriva text". Artikeln "Elever skriver" är omarbetad och finns inte kvar i sin ursprungliga form.
} 
Tabell 1. Materialöversikt

\begin{tabular}{lll}
\hline & SAMTAL 1 & SAMTAL 2 \\
\hline TYP AV MODUL & generell literacy & generell literacy \\
TYP AV GRUPP & heterogen & homogen \\
ANTAL DELTAGARE & 9 & 5 \\
SAMTALETS LÄNGD & $82 \mathrm{~min}$ & $55 \mathrm{~min}$ \\
ANTAL TURER & 408 & 239 \\
\hline
\end{tabular}

att mer ingående beskriva dem eller de skolor där de är verksamma. Lärarnas namn har ersatts med beteckningen Lärare A, B, C eller Lärare 1, 2 och 3 osv. Vi har inte själva varit närvarande vid inspelningstillfällena. Därmed saknas också underlag för att analysera meningsskapande resurser som gester och blickar.

I materialet har interaktioner om fortbildningssatsningens literacyinnehåll fokuserats. Dessa interaktioner har i ett första steg analyserats utifrån hur samtalsobjekt etableras i samtalen och i ett andra steg hur deltagarnas olika utsagor och hållningar bidrar till kunskapsbygget om literacy. De analytiska verktyg som använts presenteras i följande avsnitt.

\section{Analytiska verktyg}

I följande avsnitt presenteras studiens analytiska verktyg, som främst hämtas från samtalsforskning och från forskning om literacy. Fokus i analysen av de båda samtalen ligger på hur lärarnas utsagor bidrar till att bygga kunskap om literacy och den roll handledaren spelar. Ett villkor för att det ska ske ett meningsutbyte i ett samtal mellan dess deltagare är att intersubjektivitet uppnås (se t.ex. Linell, 2017). Intersubjektivitet kan beskrivas som att deltagarna kommer överens om vad man pratar om. Detta har beskrivits som samtalets objekt, the object of stance (Du Bois, 2007). Samtalsdeltagarna behöver inte vara överens om hur samtalets objekt ska värderas, utan de kan positionera sig på olika sätt i relation till samtalsobjektet. Däremot måste deltagarna vara överens om vad objektet är för att samtalet inte ska bryta samman.

Det är dock vanligt att det i samtal finns ett önskemål om att uppnå en hög grad av samförstånd: "their interaction will normally serve to increase the range of sharedness" (Linell, 2017, s.109). Eftersom intersubjektivitet görs i dialog kan den analyseras genom deltagarnas olika språkliga bidrag i samtalet, till exempel stödsignaler, parafrasering och bekräftelser av berättelserundor (jfr Norrby, 2014).

Deltagarna i ett samtal kan alltså ha olika hållning, (eng. stance), till ett objekt. I enlighet med Kärkkäinen (2006) skiljer vi mellan epistemisk hållning, affektiv hållning och evaluerande hållning. Med en epistemisk hållning markerar deltagarna sin förståelse av det aktuella objektet, med en affektiv hållning sin attityd till objektet och med en evaluerande hållning visar deltagarna sin värdering av objektet (se vidare Melander \& Sahlström, 2010). 
Handledarna i Läslyftet har alla en bakgrund som lärare i något av svenskämnena och har därför genom sin utbildning förvärvat grundläggande kunskap om literacy och elevers läs- och skrivutveckling. Denna kunskap förstärks under handledarutbildningen med syfte att handledarna ska ha en viss beredskap att vid behov kunna stötta kollegors kunskapsbygge genom att på olika sätt mediera artikelinnehåll (jfr Carlbaum et al., 2016, 2017). Vi har beskrivit det som att handledaren blir en slags literacyexpert på artiklarnas innehåll i förhållande till en del av kollegorna. Genom denna expertroll ges handledaren en form av tolkningsföreträde av innehållet. Analytiskt kan dessa tre dimensioner av handledarrollen beskrivas som att handledaren har epistemisk tillgång, epistemiskt ansvar och epistemiskt företräde (Stivers et al., 2011).

Eftersom Läslyftet syftar till att stärka lärares kompetens att arbeta språk- och kunskapsutvecklande är det relevant att undersöka de föreställningar om literacy som framträder under samtalen, och hur dessa föreställningar eventuellt påverkar lärarnas kunskapsbygge. För denna analys används dels Ivaničs diskursanalytiska ramverk (2004), dels olika perspektiv på tal och skrift (se Karlsson, 2011).

I vår avslutande diskussion om vilket kunskapsbygge som framträder i samtalen applicerar vi Marianis modell för undervisning och lärande på studiens resultat (Mariani, 1997). I modellen beskrivs relationen mellan stöttning och utmaning. För ett idealt lärande föreslås att såväl stöttning som utmaning ska vara hög.

\section{Resultat och diskussion}

I följande avsnitt redovisas analysen av de båda samtalen var för sig. Först presenteras samtal $1 \mathrm{i}$ den ämnesmässigt heterogena gruppen på ett yrkesprogram på gymnasiet. Därefter presenteras samtal 2 i den ämnesmässigt homogena gruppen svensklärare på grundskolans mellan- och högstadium.

\section{Från epistemisk till evaluerande hållning - hur artikeln görs irrelevant i samtalet}

I samtal 1 ska artikeln "Att bearbeta text före läsandet” (Hallesson \& Visén, 2016) diskuteras. Denna artikel är den tredje av åtta i modulen "Språk- och kunskapsutvecklande arbete", som riktar sig till alla lärare i gymnasieskolan och introduceras på följande sätt av artikelförfattarna: "Artikeln i A-momentet beskriver dels textstrukturer och hur du som lärare kan förbereda arbetet med de egna ämnestexterna, dels klassrumsaktiviteter inför elevers läsande."

Samtalsstrukturen utmärks av en inledande runda, där varje deltagare ges möjlighet att kommentera artikeln. Under inledningsrundan nominerar handledaren nästa talare. Rundan består av 60 turer och inleds med att handledaren uppmanar alla deltagare att säga något om texten. Handledaren ger ordet till Lärare B:

(15) HL: Vi kör väl igång då, och funderar lite på vad vi tyckte om texten, om alla funderar lite, så går vi varvet runt, precis som vi gjorde för några veckor sen och så får ni säga några korta tankar kring texten (...) Ska B börja? 
Ganska omedelbart börjar deltagarna värdera artikelinnehållet. Istället för att inta en, utifrån fortbildningsmodellen, förväntad epistemisk hållning ger deltagarna uttryck för en evaluerande hållning i relation till artikelinnehållet:

(16) Lärare B: Jag kan börja. Jag tycker att det här ordet textaktivitet ställer till det lite

(54) R: $\quad$ alltså jag vacklar liksom fram och tillbaks när jag läser en sån här text för här är ju många saker som är liksom handkraft som ni kan ha nytta av, sen kan jag tycka att ibland går man väldigt djupt språktekniskt

(62) Lärare E: jag tyckte också det var en väldigt jobbig och svårtolkad text, jag fick läsa den två gånger men jag tycker det är svårt att ta fasta på den

(70) Lärare F: sen tycker jag att det här textaktivitet, det var ju ett konstigt ord, det håller jag med om, men den här instruktionen tycker jag var jättebra, den tabellen man har gett där

En bidragande orsak till den evaluerande hållningen kan vara handledarens uppmaning till deltagarna att redogöra för vad de tyckte om texten. Deltagarna enas om att artikelinnehållet är svårtillgängligt. Yrkeslärarna för också fram åsikten att innehållet är irrelevant för deras praktik och att arbeta som artikeln föreslår vore bortkastad tid:

(27) Lärare A: alltså (...) jag har egentligen tankar om att involvera mina elever i det här, hm, det är detsamma som att vi kastar bort en timme (...) det är det

(28) HL: $\quad$ så att involvera eleverna är att kasta bort en timme, hur tänker du då

(29) Lärare A: alltså hälften av dom kan ju inte läsa överhuvudtaget ju och dessutom börja bearbeta en text och börja snacka om nominaliseringar och hit och dit det har jag inte fått att fungera faktiskt

I denna fas av samtalet intar handledaren en strikt moderatorroll. Till skillnad från övriga deltagare redogör handledaren inte för sin läsning av artikeln och undviker därmed att göra bruk av sin förmodat epistemiska tillgång. Begrepp, som deltagarna lyfter fram som problematiska, exempelvis textaktivitet, kommenteras inte men handledaren säger att de ska komma tillbaka till dem senare i samtalet: (61) "mm, jag skriver upp här, så kommer vi säkert tillbaks till det. Bra. Lärare E?” Det sker inte.

\section{Undervisning om literacy som samtalsobjekt}

Syftet med den inledande rundan är att få en bild av deltagarnas läsning av artikeln för att därefter gemensamt kunna välja ut de samtalsämnen som upplevs som mest angelägna (jfr strukturen för kollegahandledning). Under rundan dokumenterar handledaren de olika bidragen och markerar tydligt när rundan är avslutad. Utifrån sina anteckningar föreslår handledaren sedan vad som ska göras till utgångspunkt för det fortsatta samtalet, nämligen svårigheten att koppla artikelinnehållet till undervisningen. Ingen av deltagarna har någon invändning mot handledarens förslag: 
(75) HL:

mm då är det ju jätteintressant att höra. Här finns många och olika tankar men det är ju fler som har pratat om det här med svårigheten att förankra det $\mathrm{i}$ sin egen undervisning och svårigheten hur ska koppla det och hur ska man göra. (...) Lärare C viftade först

Under de hundratalet samtalsturer som följer har deltagarna svårigheter att göra undervisning om literacy till ett gemensamt samtalsobjekt, object of stance. Handledaren företräder med stöd av svenskläraren (Lärare $F$ ) och rektor (R) en syn på literacy som bygger på skriftbruk medan yrkeslärarna (lärarna A-E) ger uttryck för att kunskapsöverföring inte sker genom läsning av text utan muntligt genom dialog och diskussion: (115) "Du kan inte ha texter", fastslår Lärare A. I påföljande tur (116) försöker handledaren att introducera en literacysyn som inbegriper bild och film, och som brukar beskrivas som ett vidgat textbegrepp: "men jag tänker också så här, att text det behöver ju inte vara text, det kan ju va att ni tittar på en film, att ni har traktorn framför er, ni behöver inte fastna i att det här måste va en skriven text, kan man då tänka”.

Handledarens försök att etablera föreställningen om ett utvidgat textbegrepp som ett sätt att se på literacy avvisas. Istället återkommer skiljelinjen mellan en skriftburen och en muntlig undervisning (jfr Karlsson, 2011):

(167) Lärare C: jag vet inte, jag har nog hakat upp mig på det här att det ska va en text dom ska läsa, jag tror jag har fastnat där totalt, för det är ju muntliga instruktioner hela tiden

(168) HL: $\quad$ så hur gör du då om du ska gå igenom nytt - är det med hela klassen då?

(169) Lärare C: nej, nej, nej, nej det är hela tiden individuellt, det är det och då kan man ju som Lärare A säger, en del kan man ge lite mindre instruktioner och en del får man ju nästan hålla i handen för att de ska göra nåt $[\ldots]$ men som sagt det är hela tiden muntligt

Ytterligare en svårighet att göra undervisningen om literacy till ett samtalsobjekt är knuten undervisningspraktiken. Här kolliderar två olika sätt att organisera undervisning: helklassundervisning, där läraren introducerar ett kunskapsinnehåll för en grupp elever och där samtliga elever arbetar med samma moment, och ett annat sätt som bygger på principer om mästare-lärling, där läraren instruerar elever individuellt eller i en mindre grupp, och där eleverna arbetar med olika moment:

(121) Lärare C: då har vi ju nästa där då, att det är ju ingen, det är ju sällan man har helklassundervisning på samma sak

(122) HL: Ja

(123) Lärare C: utan dom håller ju på med en massa olika

Skillnader i hur de olika lärarkategorierna lägger upp undervisningen återkommer i flera turer. Det objekt som deltagarna slutligen når en samsyn om och där lärarna har en gemensam bild av praktiken gäller eleverna. Dels bedöms flera elever sakna nödvändiga förkunskaper: (123 forts.) "Och sen det här med förkunskaper, en del, dom har ju ingenting". Dels beskrivs eleverna som ofokuserade och okoncentrerade: 
(147) Lärare D: Vi har ju så olika kategorier av elever ju. Vi har ju två stycken till exempel som pratar hela tiden [...] Och sen har vi nåra stycken som inte säger halv sju, alltså att få dom in i sånt här, det är inte lätt

I denna del av samtalet redogör lärarna för episoder där heterogena elevgrupper på olika sätt beskrivs som en utmaning i undervisningen. Såväl yrkeslärare som ämneslärare verkar dela denna uppfattning. Att samsyn uppnåtts manifesteras av hur Lärare A väljer att parafrasera Lärare F:s yttrande:

(177) Lärare F: dom har ju svårt att koncentrera sig

(178) Lärare A: ja dom har mycket svårt att koncentrera sig

Något gemensamt kunskapsbygge om ämnestexter och deras uppbyggnad sker inte i detta samtal. Det som är uppe till förhandling är vad som fungerar i klassrummet (jfr Little, 2002), och här lyckas deltagarna inte nå någon samsyn. Istället blir eleverna det objekt som deltagarna förhåller sig till på ett likartat sätt. Ur ett deltagarperspektiv tycks det bero på två saker: att modulinnehållet upplevs som irrelevant för de fem yrkeslärarna och att eleverna inte är mottagliga för det innehåll som presenteras: (104) "Det fungerar ju inte i en undervisningssituation, nåt av det, med dom eleverna vi har, det funkar inte", slår Lärare A fast. I detta samtal ser lärarna därmed ut att lägga över problemet med att genomföra en undervisning i linje med fortbildningssatsningen på eleverna.

\section{Långa berättelserundor och en delad bild av undervisningspraktiken}

I samtal 2 ska artikeln "Elever skriver" (Randahl \& Wengelin, 2015) diskuteras. Denna artikel är den sjunde av åtta i modulen "Att tolka och skriva text i skolans alla ämnen" som riktar sig till alla lärare i grundskolan, och beskrivs på följande sätt av artikelförfattarna: "Del 7 handlar om vad vi gör när vi skriver och hur skrivkompetens utvecklas. Såväl den tidiga som den fortsatta skrivutvecklingen beskrivs med hänvisning till forskning och skrivdidaktiska modeller."

I samtal 2 finns ingen tydlig inledande runda som struktur. Handledaren nominerar inte heller näste talare utan inleder: (5) "Är det nånting ändå som ni hunnit fastna för?” Liksom i samtal 1 ger handledaren övriga deltagare företräde att formulera sina tankar utifrån läsningen av artikeln, innan hon, till skillnad från handledaren i samtal 1 , presenterar sin egen läsning. Under hela samtalet faller deltagarna varandra i talet.

Samtal 2 kan karakteriseras som ett antal insprängda berättelserundor (Norrby, 2014), som i olika omfattning anknyter till artikelinnehållet, men utan att på djupet diskutera det. En av berättelserna handlar om hur Lärare 1 arbetat med kamratrespons i en av sina klasser. Berättelsen inleds: (10) " [...] min förra 5:a som jag hade på Söderskolan, där jobbade dom med Skriv texten och så hade dom kamratrespons”. I en annan berättelse signalerar samma deltagare att hon vill berätta något som saknar anknytning till artikelns innehåll: (20) " [...] vi kommer lite granna från ämnet (...) jag bara måste berätta”. Läraren återger föregående dags svensklektion där hennes 
"stökiga" klass tog initiativ till en förlängd tyst minut för offren $\mathrm{i}$ ett bombattentat. Berättelsen avslutas: (20) "jag lovar, den klassen är inte tysta. Dom satt i 10 minuter helt tysta. Jag tog tiden. Dom fixade det."

För att intersubjektivitet ska uppnås har tidigare forskning visat (se t.ex. Norrby, 2014) att berättelser måste bekräftas av någon deltagare, innan samtalet kan gå vidare. Om bekräftelse uteblir eller om berättaren anser att åhöraren missförstått innehållet gör berättaren förtydliganden. I följande exempel bekräftar handledaren Lärare $1: \mathrm{s}$ berättelse, och Lärare 1 verifierar att handledaren gjort en korrekt tolkning:

(21) HL: Vad fint

(22) Lärare 1: Det var så fint. Det var verkligen så där, man bara kände: vad dom kan, när dom har bestämt sig

Värt att notera förutom bekräftelsen i sig är att parafraseringen "Vad fint" och "Det var så fint" ytterligare stärker analysen att intersubjektivitet uppnåtts om hur berättelsen skulle tolkas.

Att samsyn uppnås i detta samtal synliggörs också på andra sätt. Förutom att bekräfta varandras berättelser visar analysen att deltagarna även har en delad bild av undervisningspraktiken. Det manifesteras språkligt till exempel genom att lärarna använder "man" och "vi" för att signalera en allmän föreställning om hur svensklärare gör i sin skrivundervisning:

(35) HL: $\quad \boldsymbol{v i}$ håller på och $\boldsymbol{m a n}$ bedömer och $\boldsymbol{m a n}$ ger respons och $\boldsymbol{m a n}$ vill att det ska utvecklas och så, och det tar jättemycket tid. Jag menar inte, jag tycker inte att det är bortkastad tid, bara att man kunde effektivisera det lite [...]

(36) Lärare 1: [...] Det tror jag att $\boldsymbol{v i}$ har upplevt allihopa som lärare (...) man får inte (...) alltså man lämnar ut den här responsen till eleven och så tittar eleven på det, och så blir det inte så mycket mer utav $\operatorname{det}[\ldots]$

(37) Lärare 3: [...] Dom ska förstå varför dom ska få respons. Jag har ju dom som läser det här men skiter högaktningsfullt i vad det är för nåt (...), men då har man givit dem möjlighet att förbättra sin text.

Även om lärarna har olika utbildning och arbetar på olika stadier tycks identiteten som svensklärare spela en roll här. Den gemensamma synen på undervisningspraktiken, menar vi, leder till att lärarna börjar dela med sig av undervisningsmaterial, till exempel lektionsupplägg, matriser och läromedel. Följande exempel illustrerar hur Lärare 2 delar en matris som hennes elever ska använda för att ge kamratrespons på sagor:

(134) Lärare 2: Jag har gjort en [matris] på saga nu, för vi ska skriva sagor. Då har jag gjort en stödstruktur till det. Kanske kan jag ge dig nästa gång? [...]

(135) Lärare 1: Alltså, jag är jättetacksam

(136) HL: Jag känner att du kommit längre än jag gjort i detta, så va (...) men det är ju så lätt att pdf:a över det och slänga över på mejlen till varandra och så där 
(137) Lärare 2: Ja, faktiskt, för det är ju ett sätt att klara det

(138) Lärare 3: Ja, dela och lär

Trots att lärarna har en gemensam syn på undervisningspraktiken är det tveksamt om samtalet utmynnar i att ny kunskap byggs. Istället karakteriseras det kollegiala samtalet av ett erfarenhetsutbyte, där lärarna även delar material med varandra (jfr Little, 2002). Samtalet kretsar mer runt lärarnas tidigare erfarenheter än runt själva artikelinnehållet. Handledaren gör flera försök att förankra samtalet tydligare i artikelinnehållet genom explicita hänvisningar till artikeln: (138) "det står i texten också [...] det här kompensatoriska uppdraget”. I just detta fall väljer lärarna att diskutera skolans likvärdighetsproblem på samhällsnivå, med fokus på bostadssegregation snarare än att lyfta frågan om kompensatorisk undervisning.

Även i synen på literacy finns det stora likheter mellan deltagarna. Samtliga positionerar sig i en processorienterad skrivdiskurs (jfr Ivanič, 2004). Artikeln lyfter också fram en annan syn på literacy som bygger på en genrepedagogisk diskurs, men den får ett mycket begränsat utrymme i samtalet. Här hade handledaren sannolikt behövt utmana kollegornas samsyn för att skapa förutsättningar för en fördjupad literacyförståelse. Samtidigt finns det inte några signaler från deltagarna att artikelns avsnitt om genrepedagogik skulle vara obekant eller svårtillgängligt. Handledaren får därmed inget incitament att ta en slags expertroll i samtalet.

\section{Det uteblivna kunskapsbygget}

Som svar på vår fråga om vilket kunskapsbygge om literacy som sker i de båda samtalen konstaterar vi att tecken på ny eller fördjupad förståelse saknas. I följande avsnitt försöker vi utifrån vår analys att utreda varför.

I analysen av samtal 1 har vi identifierat flera möjliga orsaker. För det första görs artikelinnehållet irrelevant, dels genom att deltagarnas intar en evaluerande hållning till innehållet, dels genom att handledaren väljer en strikt moderatorroll. I samtalet finns tydliga signaler om att flera av deltagarna inte har förstått delar av innehållet. Även om man kan förmoda att handledaren är den deltagare som både har epistemisk tillgång och epistemiskt företräde när det gäller artikelns innehåll undviker handledaren rollen som en slags literacyexpert. Den inledande rundan får därmed en närmast negativ effekt på ett kollegialt lärande och en fördjupad förståelse av det innehåll som artikeln vill förmedla.

För det andra saknas en gemensam syn på literacy bland deltagarna (jfr Stoll et al., 2006). Snarare framträder en tydlig skillnad mellan yrkesämnets muntliga kultur och övriga skolämnens skriftburna kultur. Läslyftet har som mål att utveckla elevers läs- och skrivkompetens, men eftersom yrkeslärarna uttrycker att de inte undervisar utifrån texter kan deras utsagor också förstås som att de ifrågasätter sitt deltagande i fortbildningssatsningen.

För det tredje saknas en gemensam bild av undervisningspraktiken. Om handledaren har epistemiskt företräde i relation till artikelinnehållet tycks handledaren sakna 
epistemiskt företräde när det gäller delar av praktiken, främst undervisningen i verkstaden. Det kan vara en bidragande orsak till att handledaren förlorar möjligheten att styra och förankra denna fas av samtalet $i$ frågor som rör literacy och att skapa förförståelse och bygga förkunskaper i undervisning:

(133) HL: $\quad$ Men Lärare C, jag tänker det med att när vi väl kommer till det att vi ska börja planera lektion, det är kanske så här att du ska bara testa med just de här tre eleverna som jobbar med det här momentet den här lektionen? Du kanske inte ska tänka att du ska ha hela klassen.

(134) Lärare C: men var ska jag ta eleverna ifrån då?

(135) HL: $\quad$ Men du sa ju att dom jobbar i grupper med olika saker

(136) Lärare C: Men dom skriker ju hela tiden

(137) HL: $\quad$ Aha, du menar så

(138) Lärare C: Ja, dom behöver ju hjälp

(139) Lärare A: Jo, men det är ju jättebra, om vi är 16 i klassen och kan vara fyra lärare, då skulle det funka

(140) Flera: $\quad \mathrm{Mm}$, jaa

I vår analys har vi intresserat oss för hur frågor om intersubjektivitet påverkar kunskapsbygget. I samtal 1 tycks handledaren även möta motstånd från vissa av deltagarna som måste hanteras. Tidigare studier (Mitchell et al., 2010) har visat att handledare i liknande situationer framförallt använder sig av strategin att försöka skapa tillit och respekt i gruppen och för projektet som sådant genom att till exempel bekräfta deltagarnas bidrag och upplevelser och att släppa kontrollen över innehållet. Det är något som vi ser sker även i detta samtal. Samtidigt frågar vi oss ändå om handledaren inte hade kunnat ta ett större epistemiskt ansvar, framförallt i ett samtal som detta, där fokus ligger på att etablera en gemensam förståelse av ett specifikt innehåll. Dels hade handledaren kunnat redogöra för sin egen förståelse av artikelns innehåll, dels fånga upp den brist på epistemisk tillgång som deltagarna signalerar.

I samtal 2 gör deltagarna B-samtalet till ett tillfälle för erfarenhetsutbyte. Främsta anledningen är sannolikt att artikelns innehåll inte är tillräckligt utmanande för svensklärarna. Handledaren konstaterar också en bit in i samtalet att innehållet är så självbärande att det knappast behöver medieras: (184) "Kände spontant, den här texten var lite mer lättillgänglig."

En annan anledning till det uteblivna kunskapsbygget tycks vara deltagarnas samstämmiga syn på literacy. Deltagarna positionerar sig i samma processorienterade skrivdiskurs (Ivanič, 2004) och ger inte uttryck för att de genom artikeln har fått nya insikter om skrivundervisning eller elevers läs- och skrivutveckling. Lärarnas gemensamma positionering blir här snarare ett hinder än en förutsättning för att kunna bygga ny kunskap tillsammans. För att sammanfatta svaren på studiens tre forskningsfrågor kan vi konstatera att det kunskapsbygge som sker $\mathrm{i}$ de båda kollegiala samtalen är begränsat. En viktig orsak ser ut att vara deltagarnas skilda föreställningar och kunskaper om literacy som artikelinnehållet inte 


\section{A.-C. Randahl och P. A. Varga}

förmår möta. En annan orsak är möjligen de samtalsmodeller som fortbildningssatsningen förespråkar, där handledarens kunskaper om artikelinnehållet inte tas i anspråk. Trots studiens begränsade omfattning menar vi att våra resultat synliggör reella utmaningar i denna typ av fortbildningssatsningar - både när det gäller uppdraget att leda satsningen, i detta fall en handledare som leder kollegiala samtal, och när det gäller fortbildningsmaterial som riktar sig till heterogena målgrupper.

Genom att applicera studiens resultat på Marianis modell (1997) framgår att inget av de båda kollegiala samtalen, som vi har studerat, går att placera i vad som brukar beskrivas som en ideal lärande- och utvecklingszon (se Figur 3).

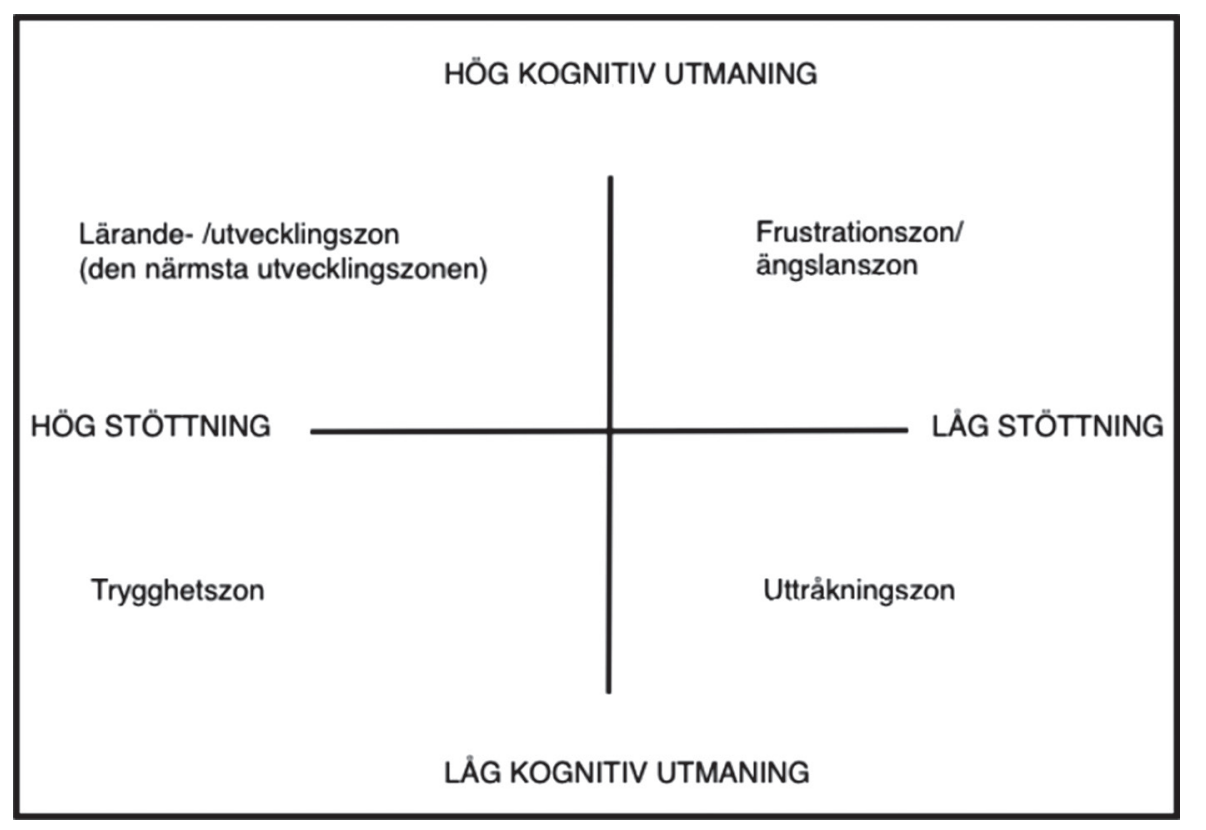

Figur 3. Undervisningens och lärandets fyra zoner (Mariani, 1997 i Gibbons, 2010, s. 44)

I samtal 1 är utmaningen hög men stöttningen låg. Flera deltagare ger uttryck för att artikelinnehållet är svårtillgängligt, vilket kan förklaras av deras olika erfarenheter av, syn på och kunskaper om literacy. Samtidigt tar inte handledaren rollen som en slags literacyexpert. Samtalet placerar sig därmed snarast i en slags frustrationszon. I samtal 2 är utmaningen låg vad gäller artikelns innehåll och ingen av deltagarna signalerar att artikelinnehållet är svårtillgängligt. Handledaren har därmed inget innehåll att mediera och väljer att bekräfta deltagarnas erfarenhetsbaserade yttranden snarare än att utmana dem. Resultatet blir att stora delar av artikelinnehållet inte kommer upp till diskussion. Samtalet placerar sig därmed snarast $\mathrm{i}$ en trygghetszon. 


\section{Slutsatser}

Vi vill avslutningsvis lyfta blicken från de båda samtalen och granska några av de förutsättningar som ligger till grund för satsningen. Läslyftet bygger på en modell för kollegialt lärande som utprövats och genomförts i en tidigare statlig fortbildningssatsning, Matematiklyftet. Utvärderingar av denna satsning (Österholm et al., 2016) ger en i huvudsak framgångsrik bild, medan de utvärderingar som gjorts av Läslyftet ger en mer splittrad bild (Carlbaum et al., 2016, 2017). Resultaten i vår studie ger anledning att jämföra de båda fortbildningssatsningarna och ställa frågor om modellens överförbarhet och handledaruppdragets komplexitet.

Matematiklyftet vände sig till en ämnesmässigt homogen grupp. Det finns skäl att anta att innehållet $i$ artiklar och filmer upplevdes som relevant för deltagande lärare, eftersom de alla undervisade i ämnet matematik. I Matematiklyftet var de olika modulerna anpassade efter skolform, vilket gjorde att innehållet lättare kunde anpassas till deltagares förkunskaper och elevgruppens förutsättningar. Eftersom samtliga deltagare var matematiklärare kunde det matematiska ämnesspråket användas som en resurs i de kollegiala samtalen för att bygga kunskap gemensamt i ämnet. Det språk och de begrepp som används för att tala om texter och elevers literacyutveckling delas däremot inte med självklarhet av alla deltagare som Läslyftet vänder sig till. En språkvetenskaplig diskurs kan inte användas utan att deltagarna först erövrar vissa språkvetenskapliga begrepp. I Matematiklyftet delar handledaren ämnestillhörighet med deltagande lärare. Det gör att varje handledare också har tillgång till ämnets undervisningspraktik. I samtal 1 lyckas deltagarna inte skapa en gemensam bild av textbruk i undervisningen, vilket i sin tur gör artikelinnehållets relevans för undervisningen hart när omöjlig att påvisa - och komplicerad att diskutera.

Detta sammantaget, menar vi, gör handledarens uppdrag i Läslyftet betydligt mer komplext jämfört med i Matematiklyftet. Det är inte bara den typ av gängse motstånd mot satsningar på kollegialt lärande som initieras uppifrån som handledaren har att hantera (jfr Talbert, 2010). I jämförelse med Matematiklyftet finns i Läslyftet inte samma gemensamma bild av undervisningens vad, hur och varför, som varje deltagande lärare kan relatera till (jfr Johansson \& Magnusson, 2019). Att etablera literacy som ett gemensamt lärandeobjekt för Läslyftets breda målgrupp verkar kräva att handledarens roll som moderator kompletteras av en roll där handledarens epistemiska tillgång tas tillvara i högre utsträckning. De samtalsmodeller som får stort utrymme i handledarutbildningen utgår från delvis andra premisser än att ett specifikt innehåll först ska förstås och sedan relateras till egen kontext. I modellerna ges handledaren heller inte något epistemiskt ansvar för att mediera detta innehåll.

Kontexten för de kollegiala samtalen skiljer sig åt på avgörande punkter i de båda satsningarna. Det finns skäl att anta att sådana skillnader påverkar det gemensamma kunskapsbygget. Studiens resultat ger också anledning att problematisera fortbildningsmaterialet i Läslyftet. Möjligen har Skolverket överskattat tanken att skolans organisation med ämnesmässigt heterogena arbetslag bäst möts av moduler med ett 
generellt literacyinnehåll. Att alla lärare är språklärare är en tanke som har haft svårt att få fäste i skolans verksamhet. Kanske hade fortbildningssatsningen vunnit på att istället tydligare skriva fram språket som vårt främsta redskap för att bygga kunskap och som en konsekvens av det skapa ett material som fokuserar en språk- och kunskapsutvecklande undervisning inom vart och ett av skolans ämnen.

\section{Forfattarbiografi}

Ann-Christin Randahl är fil.dr i svenska språket. Hon arbetar som lektor med didaktisk inriktning på institutionen för svenska språket vid Göteborgs universitet. Från november 2016 har hon ett uppdrag som postdoktor inom ramen för det VRfinansierade projektet "Fortbildning på Facebook" vid Karlstads universitet.

Pernilla Andersson Varga är fil.dr i ämnesdidaktik med inriktning mot svenska. Hon arbetar som lektor med inriktning likvärdighet i språk- och kunskapsutveckling på Center för Skolutveckling i Göteborg.

\section{Referenser}

Bolam, R., McMahon, A., Stoll, L., Thomas, S., Wallace, M., Greenwood, A., Hawkey, K., Ingram, M., Atkinson, A. \& Smith, M. (2005). Creating and sustaining effective professional learning communities (Research Report 637). DfES and University of Bristol.

Carlbaum, S. Andersson, E. \& Hanberger, A. (2016). Utvärdering av Läslyftet. Delrapport 2: Erfarenheter av Läslyftet läsåret 2015/16. Umeå Centre for Evaluation Research (UCER).

Carlbaum, S. Andersson, E. \& Hanberger, A. (2017). Utvärdering av Läslyftet. Delrapport 4: Erfarenheter av Läslyftet i gymnasieskolan 2016/17. Umeå Centre for Evaluation Research (UCER).

Cummins, J. (2017). Flerspråkiga elever: effektiv undervisning $i$ en utmanande tid (1. utg.). Natur \& Kultur.

Du Bois, J. W. (2007). The stance triangle. I R. Englebretson (Red.), Stancetaking in discourse: Subjectivity, evaluation, interaction (s. 139-182). John Benjamins Publishing.

Erixon, P-O. \& Löfgren, M. (2018). Ett demokratilyft för Sverige? Om relationen mellan literacy, skönlitteratur och demokrati i Läslyftet. Utbildning E Demokrati, 27(3), 7-33. http://umu.diva-portal.org/smash/get/ diva2:1305478/FULLTEXT01.pdf

Fjørtoft, H. (2016). Leseveiledere i grunnskolen. Vurderingens rolle i tverrfaglig samarbeid. I H. Fjørtoft \& L. V. Sandvik (Red.), Vurderingskompetanse i skolen. Praksis, laring og utvikling (s. 123-138). Universitetsforlaget.

Gibbons, P. (2010). Lyft språket, lyft tänkandet: språk och lärande. Hallgren \& Fallgren.

Hallesson, Y. \& Visén, P. (2016). Att bearbeta text - före läsandet. I läslyftsmodulen Språk- och kunskapsutvecklande arbete. https://arportalen.skolverket.se/LarportalenAPI/api-v2/document/path/ larportalen/material/inriktningar/5-las-skriv/Gymnasieskola/018_sprak-o-kunskapsutveckl-arb/ del_03/3.\%20Att\%20bearbeta\%20text\%20-\%20före\%20läsandet.pdf

Hargreaves, A. \& Fullan, M. (2013). The power of professional capital. With an investment in collaboration, teachers become nation builders. Fournal of Staff Development, 34(3), 36-39. https://learningforward.org/ journal/international-trends/power-professional-capital/

Ivanič, R. (2004). Discourses of writing and learning to write. Language and Education, 18 (3), 220-245. https:// doi.org/10.1080/09500780408666877

Jarl, M., Blossing, U. \& Andersson, K. (2017). Att organisera för skolframgång: strategier för en likvärdig skola. Natur \& Kultur.

Johansson, M. \& Magnusson, P. (2019). Läslyftet i praktiken. Analys av ett textmaterial och ett lärarlags samtal. Acta Didactica Norge, 13(1), Art. 6. https://doi.org/10.5617/adno.5632

Karlsson, A.-M. (2011). Great divide, social practice eller motivated sign? Materiella, sociala och semiotiska perspektiv på skriftspråkande. I A. Edlund \& I. Mellenius (Red.), Svenskans beskrivning 31. Förhandlingar vid Trettioförsta sammankomsten för svenskans beskrivning, Umeå den 20-21 maj 2010. Umeå universitet. 


\section{Kollegiala samtal som kontext för utveckling av lärares literacyförståelse}

Kvale, S. \& Brinkmann, S. (2014). Den kvalitativa forskningsintervjun. Studentlitteratur.

Kärkkäinen, E. (2006). Stance taking in conversation: From subjectivity to intersubjectivity. Text $\mathcal{E}$ Talk, 26(6), 699-731. https://doi.org/10.1515/TEXT.2006.029

Lahdenperä, P. \& Sundgren, E. (Red.). (2017). Nyanlända, interkulturalitet och flerspråkighet $i$ klassrummet. Liber.

Larsson, P. (2018). Kollegialt lärande och konsten att navigera bland begrepp. I N. Rönnström \& O. Johansson (Red.), Att leda skolor med stöd i forskning: exempel, analyser och utmaningar (s. 389- 415). Natur \& Kultur.

Lauvås, P., Lycke, K. H. \& Handal, G. (1997). Kollegahandledning i skolan. Studentlitteratur.

Linell, P. (2017). Intersubjectivity in dialogue. I E. Wegand (Red.), The Routledge handbook of language and dialogue (s. 109-126). Routledge.

Little, J. W. (2002). Locating learning in teachers' communities of practice: Opening up problems of analysis in records of everyday work. Teaching and Teacher Education, 18(8), 917-946. https://doi.org/10.1016/S0742051X(02)00052-5

Mariani, L. (1997). Teacher support and teacher challenge in promoting learner autonomy. Perspectives, 23(2). https://www.learningpaths.org/papers/papersupport.htm

Melander, H. \& Sahlström, F. (2010). Lärande i interaktion. Stockholm: Liber.

Minten, E. (2013). Forskning för klassrummet: vetenskaplig grund och beprövad erfarenhet $i$ praktiken. Skolverket.

Mitchell, J., Riley, P. \& Loughran, J. (2010). Leading professional learning in schools: emotion in action. Teacher Development, 14(4), 533-547. https://doi.org/10.1080/13664530.2010.533495

Muijs, D. \& Harris, A. (2003). Teacher leadership - Improvement through empowerment?: An overview of the literature. Educational Management Administration E Leadership, 31(4), 437-448. https://doi. org/10.1177/0263211X030314007

Norrby, C. (2014). Samtalsanalys: så gör vi när vi pratar med varandra. Studentlitteratur.

OECD. (2015). Improving schools in Sweden: An OECD perspective. OECD Publishing.

Randahl, A.-C. (2017). Läslyftet och lärarnas lärande. En studie av de kollegiala samtalen. I E. Sköldberg, M. Andréasson, H. Adamsson Eryd, F. Lindahl, S. Lindström, J. Prentice \& M. Sandberg (Red.). Svenskans beskrivning. 35, Förhandlingar vid trettiofemte sammankomsten: Göteborg 11-13 maj 2016 (s. 287-300). Göteborgs universitet. https:/gupea.ub.gu.se/bitstream/2077/52211/1/gupea_2077_52211_1.pdf

Randahl, A.-C. \& Wengelin, Å. (2015). Elever skriver i Läslyftsmodulen Tolka och skriva text $i$ skolans alla ämnen. ${ }^{2}$

Scherp, H. Å. (2003). Att leda lärande samtal. Karlstads universitet.

SFS 2013: 1118. (2013). Förordning om ändring $i$ högskoleförordningen (1993:100). Utbildningsdepartementet. Stockholm.

Shanahan, T. \& Shanahan, C. (2012). What is disciplinary literacy and why does it matter? Topics in Language Disorders, 32(1), 7-18. https://doi.org/10.1097/TLD.0b013e318244557a

Skolverket. (2012). Få syn på språket: ett kommentarmaterial om språk- och kunskapsutveckling $i$ alla skolformer, verksamheter och ämnen. https://www.skolverket.se/getFile?file=2843

Skolverket. (2018). Planera och organisera för kollegialt lärande. https://www.skolverket.se/ download/18.1d7693d81684bec928237c/1547639821034/Laslyftet_skolan_planera_organisera_ kollegialt_larande_2019.pdf

Skolverket. (2019). Läroplan för grundskolan, förskoleklassen och fritidshemmet 2011: reviderad 2019. Stockholm.

SOU 2018: 17. (2018). Med undervisningsskicklighet $i$ centrum - ett ramverk för lärares och rektorers professionella utveckling: slutbetänkande. Norstedts Juridik. https://www.regeringen.se/rattsliga-dokument/statensoffentliga-utredningar/2018/03/sou-201817/

Stivers, T., Mondada, L. \& Steensig, J. (2011). Knowledge, morality and affiliation in social interaction. I T. Stivers, L. Mondada \& J. Steensig (Red.), The morality of knowledge in conversation (s. 3-26). Cambridge University Press.

Stoll, L., Bolam, R., McMahon, A., Wallace, M. \& Thomas, S. (2006). Professional learning communities: a review of the literature. Fournal of Educational Change, 7, 221-258. https://doi.org/10.1007/s10833-0060001-8

Talbert, J. E. (2010). Professional learning communities at the crossroads: How systems hinder or engender change. I A. Hargreaves et al. (Red.), Second international handbook of educational change (s. 3-26). Springer.

Thornberg, R. (2013). Det sociala livet $i$ skolan: socialpsykologi för lärare. Liber.

Timperley, H. (2008). Teacher professional learning and development (Educational Practices Series 18). International Academy of Education.

Timperley, H. (2011). Realizing the power of professional learning. Open University Press.

${ }^{2}$ Artikeln är reviderad och går inte längre att söka på Lärportalen men kan erhållas av författarna. 


\section{A.-C. Randahl och P.A.Varga}

Utbildningsdepartementet. (2013). Regeringsbeslut U2013/7215/S. Uppdrag om fortbildning iläs-och skrivutvecklingLäslyftet. https:/www.regeringen.se/regeringsuppdrag/2013/12/u20137215s/

Varga, P. A. \& Randahl, A-C. (2017). Från samtalsledare till förändringsagent? Handledarens roll i Läslyftet. I Tolfte nationella konferensen $i$ svenska med didaktisk inriktning. Textkulturer. Karlstad 24-25 nov, 2016 (s. 301321). Centrum för språk- och litteraturdidaktik vid Karlstads universitet. http://kau.diva-portal.org/smash/ record.jsf?pid=diva $2 \% 3 \mathrm{~A} 1169103 \&$ dswid $=8607$

Österholm, M., Bergqvist, T., Liljekvist, Y. \& van Bommel, J. (2016). Utvärdering av Matematiklyftets resultat: Slutrapport. Umeå universitet. 